\title{
SNOW WHITE AND THE POLAR BEARS IN THE AGE OF GLOBAL HEATING: A READING OF MARK ANTHONY JARMAN'S “MY WHITE PLANET”*
}

\author{
Claire Omhovère \\ Université Paul-Valéry Montpellier 3, EMMA
}

\section{Abstract}

Set in an age when globalization goes on a par with the rise of ecological perils, Mark Anthony Jarman's "My White Planet" (2008) relies on a parodic subversion of the Brothers Grimm's "Little Snow White" to consider the responsibility human beings incur when introducing changes in the environment that will have repercussions on the whole planet. If fairy tales do not mimetically reflect how human beings inhabit the world, but instead propose interventions that lead to a better adequacy between the two, their retellings are endowed with great ethical relevance during periods of historical mutation when the old ways no longer offer guidance and the future seems uncertain. The present essay will show that Jarman draws upon the resources of the fairy tale genre to encourage a critical revision of Canada's northern myth and the manifold forms of exploitation it has encouraged.

Keywords: Canadian literature, ecocriticism, fairy tale studies, landscape studies, petrocultures.

\section{BLANCANIEVES Y LOS OSOS POLARES EN LA ERA DEL CALENTAMIENTO GLOBAL: UNA LECTURA DE "MY WHITE PLANET», DE MARK ANTHONY JARMAN}

\section{RESUMEN}

Ambientado en una época en la que la globalización avanza a la par que el aumento de los peligros ecológicos, "My White Planet» (2008), de Mark Anthony Jarman, enarbola una subversión paródica de «Little Snow White» de los hermanos Grimm para evaluar la responsabilidad en que los seres humanos incurren al introducir cambios en el medio ambiente con repercusiones planetarias. Si los cuentos de hadas no reflejan miméticamente cómo los seres humanos habitan el mundo, sino que proponen intervenciones que conducen a una mejor adecuación entre los dos, sus reescrituras están dotadas de gran relevancia ética durante los períodos de mutación histórica cuando los modos antiguos ya no ofrecen orientación y el futuro parece incierto. El presente ensayo mostrará que Jarman recurre a los recursos del género de los cuentos de hadas para alentar una revisión crítica del mito del norte de Canadá y las múltiples formas de explotación que ha fomentado.

PAlabras Clave: literatura canadiense, ecocrítica, estudios sobre cuentos de hadas, estudios del paisaje, petroculturas.

DOI: https://doi.org/10.25145/j.recaesin.2019.78.03 
The 'opening' of the Northwest Passage, as envisioned by the European Space Agency satellite in 2007, drew an orange loop straight through the sea ice, clearing a passage in the icescape and in the imagination that had been dreamt of, and searched for, over a century ago. The dream of a passage has passed into metaphor, explicating the folly and desire of white man's exploration, set against the backdrop of maritime empires and colonial relations. The passage emerges now as the hot underbelly of that dream of expansion; a line seared through the ice, illuminating global heating. The empire of man, or Anthropocene, expanded to the limits of the atmosphere.

\section{Kathryn Yusoff, "Navigating the Northwest Passage"}

The 2007 opening of the Northwest Passage predated by a year the publication of Mark Anthony Jarman's My White Planet (2008). ${ }^{1}$ The titular reference to whiteness calls attention to the adjustments made necessary when five centuries of exploration came to an end with an event that displaced "the folly and desire of the white man" (Yusoff 299) onto a different ethical plane, as dreams of infinite expansion became thwarted with the realization of the smallness of the planet and its vulnerability to human activities. In plain, positivist terms, the globe has never been any other colour but blue, at least since that other momentous day in world history when humankind was given the first satellite views of the earth to behold in wonder. ${ }^{2}$ Viewing the planet as "white" can only result from a subjective and increasingly relative perception. The possessive form narrows the perspective to a hegemonic and geographical standpoint equated with that of a fraction of the globe's population, or with a location where the world may indeed look entirely clad in white, but only when observed from regions where snow still endures. In this sense the phrase also smacks of the environmental Darwinism that originally informed Canada's model of a white civility in the nineteenth and early twentieth centuries, when embracing the country's Nordic character was valued as the ultimate test in the selection of Canada's immigrant populations, discouraging groups allegedly weaker in body or spirit from settling in Canada (Coleman 24). The enduring impact of the discourses that have constructed the Far North as the spatial foundation of the national identity, welding race and geography together, has received sustained scholarly scrutiny in past decades, from Sherrill Grace's Canada and the Idea of North (2001) to the

* My gratitude goes to Christine Lorre-Johnston for our stimulating discussions about Jarman's work and her offering to share with me an early version of her interview with him before it went through publication. See Lorre-Johnston.

1 For Frye the Northwest Passage was a geographical reminder of Canada's inception as an obstacle to naval exploration (226). Even when they disagreed with Frye's vision of the geographical determinism thwarting Canada's development, subsequent critics also used the phrase to stress the endurance of a colonial disregard for local realities: "Everything written on the Canadian Arctic is, in effect, a northwest passage, the expression not only of the traditions but the geography and history of another world" (Moss 40).

2 The first full-view photo of the globe, the famous "Blue Marble" shot was taken on December 7, 1972 from the spacecraft Apollo 17. https://www.nationalgeographic.com/photography/photos/milestones-space-photography/. 
more recent collective volume Rethinking the Great White North: Race, Nature, and the Historical Geographies of Whiteness in Canada (2011).

Jarman's short story approaches this legacy through a provocative parody of "Little Snow White" (1812). The fairy tale first recorded by the Brothers Grimm became a planetary success with Walt Disney's animated film adaptation (1937), feeding young audiences worldwide a work ethic resting on a clearly gendered division of labour (Zipes 203). Jarman relocates the encounter between Snow White and the seven dwarves in the Arctic, one of the few places where snow endures on the planet, although it is melting fast. Seven men working on a remote station reminiscent of the installations of the DEWLine, ${ }^{3}$ rescue a starlet adrift in an offshore oilrig's emergency lifeboat. Once the young woman has been revived, she stays with the team, slowly recovering from the amnesia caused by her ordeal. But the men's esprit de corps fast erodes when disagreements start to appear among them regarding the conduct they may adopt with their ward. When the situation deteriorates, Snow White, as the narrator likes calling her, convinces him to take her back to the shore in the hope that a passing cruise ship may spot and rescue them. Their plan is met with luck and she boards the ship that will take her south, while her guardian returns to the line station. Back in Hollywood, the young woman resumes her career on TV sets, and waves through the screen to the seven dwarves who saved her from death's icy jaws.

Although the story could very well have ended at that point, it moves on to include a puzzling coda in which the polar bears that have been lurking in the preceding pages now surround the surviving men: "They know us, big carnal carnivores peeking in at our parts. It's love. They spy us in the window and are nostalgic for the happy future when they will have us in their arms" (Jarman 45, emphasis added). This variation upon the customary ending of the fairy tale recasts the romantic formula of the disenchanting kiss into an encounter with the animal spirit of the North ${ }^{4}$ which it nevertheless postpones to an already obsolete future. The temporal aporia simultaneously announces and erases the possibility of everlasting happiness, keeping in suspension the signature of the fairy tale. Jack Zipes rightly emphasizes that "fairy tales are informed by a human disposition to action -to transform the world and make it more acceptable to human needs while we try to change and make ourselves fit for the world" (2). If fairy tales do not mimetically reflect how human beings inhabit the world, but instead propose interventions that lead to a better adequacy between the two, their retellings are endowed with great ethical relevance during periods of historical mutation when the old ways no longer offer guidance and the future seems uncertain: "So massive and daunting are the environmental crises facing us -facing the earth- that nothing short of

3 The stations of the Distant Early Warning Radar Line were built all over Alaska and the Canadian North during the Cold War to detect the first signs of a Soviet invasion, when rallying the help of its closest neighbour was necessary for the USA to eavesdrop on the USSR and the rest of the Eastern block. Most of the DEWLine installations were dismantled or abandoned after 1985.

4 The Greek arktos means "bear," the name the Romans also gave to the North star, Ursa Major. 
a massive re-imagining, a shift in the imaginary will work" (Ricou 168). Set in an age when globalization 5 goes on a par with the rise of ecological perils, "My White Planet" works from a parodic subversion of "Little Snow White" to reflect upon the responsibility human beings incur when introducing changes in the environment that will have repercussions on the whole planet. The subsequent sections will show that Jarman's short story draws upon a most didactic genre to encourage a re-imagining of Canada's Far North and of the stories attached to this region of the globe.

\section{THE STORY AND ITS GENERIC AFFILIATIONS}

"Seven of us examine her. Seven men and our Snow White" (Jarman 26). The afterthought inspires a narrative line that diverges from the plain sequence of events in which a castaway is found, saved and ultimately returned to Hollywood's limelight: "I have a final golden vision of her at a microphone, many microphones aimed at her, rented jewels on her sunny neck" (Jarman 25). No sooner has the story begun than it rushes to its denouement. The first page thus condenses everything one needs to know about the outcome of an Arctic adventure which boils down to a sensational news item in this stunted form. The short story genre allegedly allows for extreme forms of compression, viz. the episodic format, condensed time-structure, fragmented narrative and open-endedness brought to perfection by Modernist writers (Nischik 37). But in the present case, the short cut may also suggest that the story lies elsewhere, perhaps in the fantasies that people the narrator's solitude, as he reminisces how the men brought the inanimate woman back to life and the lazy days of her convalescence. Because of this, "My White Planet" first comes through as a collage of erotic reveries. Daydreams about the senseless body the men lifted out of the sea prompt time-honoured associations of female forms with the ebb and flow that gave birth to the Venus Anadyomene: "Her sodden hair and skin, that naked ass coming up into view like a frozen white planet, my lovely planet" (Jarman 42-43). As Donald Barthelme in his novella Snow White (1967), Jarman embraces the postmodern conundrum of "'creat[ing] new art' out of the junkpile of the text" (Nealon 125), and resorts to an "aesthetics of trash" (McCaffery 19) that recycles literary motifs and occasionally degrades them, as in the passage above where the planet has its cosmic dimension further reduced to the proportions of a woman's sumptuous bottom. Much like the beauty spots that adorn Barthelme's heroine and are reproduced in a vertical line of dots on the story's first page (Barthelme 3), the freckles on the castaway's face and "black and white Dalmatian ice" in Jarman's version put a blemish on the pristineness the princess and her namesake originally

5 The term first appeared in the 1960s (Steger 9), but Jay traces the beginning of popular public discussion of globalization back to the turn of the new millennium (23). Jay further insists on the forces of imperial expansion which, from the Renaissance onwards, have paved the way for the rise of globalization. The Northwest Passage makes this historical conjunction geographically visible. 
stood for (Jarman 26 and 40). If we are entering the precincts of the fairy tale, someone has been here before. The narrator ushers us into a well-trodden territory, signposted with allusions to the inscriptions that have constituted the fairy tale into a literary topos. The explicit reference to a videotape of the Disney classic is preceded by a less obvious (or perhaps more donnish) hint when the narrator reflects that the amnesiac woman is "a blank slate for [him] to write on, to create" (Jarman 34 and 29 respectively), a nod to Gilbert and Gubar's interpretation of "Little Snow White" on which later feminist critics elaborated to demonstrate the "intertwined rules of sexual reproduction and narrative production" informing the tale (Bacchilega, "Cracking" 4).

References to the Disney adaptation, to Barthelme's postmodern parody, and to the critical attention the original tale and its avatars have received effectively inscribe "My White Planet" within a genealogy of texts and images, which indexes the plasticity of a genre remarkably tolerant of revisions and transformations (Bacchilega, Introduction 16). The proliferation of intertextual echoes sharply contrasts with the silence of the woman serving in Snow White's stead and the unreadability she opposes to the men's desire in this new version of the tale: "Sometimes she kisses us, sometimes she studies the seven of us, one after the other. What does she think?" (Jarman 36). The question does not befit the morphology of the tale in which characters embody formulaic functions rather than psychological motivations (Bacchilega, "Cracking" 11). But it resonates in a context where interrogations abound the moment we cross the limits of the fairy tale into another, adjacent universe of fiction, namely the tale of anticipation in which wonder shades into darker, dystopian tones.

"My White Planet" comprises allusions to historical events that, although they are never elucidated or precisely dated, call forth images audiences the world over now associate with international terrorism and military retaliation:

We inhabit a line station secretly functioning after the accord, but something went dead after June 11. Our dishes and software seem without flaw, but our screens remain blank, thoughtless. No printouts. No officiant plies us with coded orders or fervent denials or demands our narrow circumspect data. Is everyone erased in a war or did a budget-conscious computer take us out in bureaucratic oversight? We are paid puppets, but no one is pulling the strings and no cheque is in the mail.

(Jarman 26-27)

No year anchors the date in a specific time period, yet the day of the month, 6/11, eerily mirrors the precedent of 9/11, also evoked through the "engine's martial music" of the airplanes that fly over the line station (Jarman 31, 33). But the secrecy surrounding the men's occupations and their sophisticated electronic equipment hark back to a more distant past, the operations of the DEWLine and Cold War strategies, a period also conjured up through the documentaries and newsreels the men are watching on the History Channel (Jarman 33 and 39). Distinctions between past and present blur into a pervasive climate of fear, the result of several references to an airborne terror that seem to simultaneously recall and announce an imminent planetary conflict, while the men go on performing enigmatic daily duties in a "listening post where [they] don't listen" (Jarman 45). 
The isolated setting and the men's predicament cannot fail to evoke a number of postcolonial dystopias that have heralded the crumbling of empires in the wake of Dino Buzzati's The Tartar Steppe (1938). Like Buzzati's Lieutenant Drogo, the magistrate in J.M. Coetzee's Waiting for the Barbarians (1980) and the soldier in Peter Carey's "A Windmill in the West" (1980) were sent out by a central state authority to a remote frontier outpost to keep watch over a border where law and order are challenged by insidious forms of alterity. The men's isolation gradually causes their mental stability to alter and the authority they embody to disintegrate, as the dividing line between what lies inside and outside their consciousness becomes blurred. A similar process of degradation occurs in "My White Planet" as danger draws closer every time another man loses his life to the harsh conditions of an extreme environment. Their gruesome ends have their Gothic precedents in the classics of northern lore: "When you enter Arctic narrative, you enter every narrative of the Arctic ever written. When you enter the Arctic in person, you become part of the extended text," explains John Moss when reading his own exploration of Arctic space contrapuntally against the texts that have constituted the region into a setting for male tales of self-aggrandizement (105). Sherrill Grace's analysis of the Canadian North as a "chronotope" ("Gendering") and then as a "discursive formation" (Canada) has thrown light on the accretion of texts accounting for this phenomenon. The two concepts Grace successively borrows from Bakhtin and Foucault help her delineate the northern narrative that has been informing "the image of a distinctly Canadian identity comprising hardy, virile masculinity, intellectual, spiritual and racial superiority (of white, northern European stock), and imperialist authority" (Grace, "Gendering" 165), and expose its foundations in southern views of the Arctic, from classical antiquity to the exploration age and the artistic productions of the present. Grace's comprehensive approach re-injects a historical dimension into a space which Western colonizing discourse has sought to represent as conveniently devoid of a human presence, immutable and homogenous, the passive recipient of the transformations a more temperate civilization had in store for it.

How does "My White Planet" relate to the topoi constitutive of a northern narrative in which each voyage of discovery tends to turn into an enterprise of recovery, to adapt Aritha van Herk's formulation (87)? As with his handling of fairy tale and dystopian motifs, Jarman's take on Canada's northern myth causes a collision between the past and the present, pointedly recalling that Canada's polar regions have long been on the course of the emissaries of expanding empires:

We found a wooden ship on our lost satellite, stuck in ice, perhaps beached deliberately centuries before, lost men, food still on their table. Did the stiff-legged bears pick them off one by one, eating the years? Slopes of scree and ravens spying on us behind their formal wear, their Aztec razor faces.

I walk her to the wooden ship, as if we are courting, to show her the frozen Norwegian rat lying on ballast stones, stones and rats being there so long a time, born in Europe, Eurocentric rats, going nowhere now.

Have you been here almost as long? she wonders.

(Jarman 29-30, emphasis added) 
The incongruous (though euphonious) combination of "Aztec" and "razor" brings into sharp focus the ravens presiding over this scene of re/discovery and, along with their anthropomorphized profile, the populations who came over the Bering Strait some 18,000 years ago, slowly drifted south, and settled the Americas. The raven is a common enough species in the Arctic, but it is also the bird of creation, a prominent Trickster figure in Inuit mythology as in many other North-American indigenous cultures. The birds' presence opens a temporal dimension that contradicts the woman's amnesia and her falsely naïve question. Indeed, there may be some truth in the insinuation that the men do belong in this frozen tableau, insofar as they are part and parcel of the same enterprise of conquest and paranoid surveillance. This implication is further underscored by the narrator's ironical use of "Eurocentric," another anachronism bridging the gap between twenty-first-century critical recognitions and nineteenth-century persuasions when neither sailors (nor stowaway rodents) had the slightest qualm about the ideology they contributed to propagating. The resulting time-warp causes the short story to integrate a long-term perspective on a region caught in the historical development of globalizing forces that one would be mistaken to regard as a nascent phenomenon simply because they have been accelerating since the turn of the millennium (Jay 33).

Bestowing the name of Rasmussen on the story's villain sends another strong signal to the reader. When the Danish explorer first travelled the Northwest Passage by dog sleigh from Greenland to Alaska between 1922 and 1924, his prodigious victory against the geography of the Arctic put an end to centuries of competition between the European powers to trace the polar route that would give them fast and direct access to "the ocean current to Cathay" (Van Herk 82). It is then no coincidence that the character that goes by the name of Rasmussen should also embody the endurance of a male discourse of imperial domination over a colonial space conventionally gendered as female. For Rassy, as the others nicknamed him, is also the first one to suggest a gambling game to decide who will lay hand on Snow White's "blue-route map of veins and fine skin. [...] [H]er skin ice-water tight, her hip, her perfect white shores" (Jarman 28). The geographical metaphors fusing land and woman harken back to the foundations of Canada's northern myth in which the Arctic is endowed with female attributes, a cruel yet alluring force whose cold embrace only the bravest among men could withstand, as Atwood (1995) has detected. Because this topos was the object of sustained critiques in the closing decades of the twentieth century from scholars and writers alike, it is remarkable to see it resurface three decades later in Jarman's short story, albeit in a degraded, parodic form. ${ }^{6}$ Does this mean that the counter-discursive assaults of the previous century have somehow failed and that southern stories about the North are bound

${ }^{6}$ Atwood, Grace and Hulan developed complementary approaches to the conventions of Canada's northern narrative, showing how it consolidated into a national myth during Canada's formative years, before moving on to explore its subsequent revisions, especially in women's writings, from the 1980s onwards. 
to follow the same course? In this respect, the narrator's sexual fantasies would seem to perpetuate the gendered expression of a century-old logic of territorial exploration followed by occupation and control. Or could the rhetoric of excess displayed in "My White Planet," beginning with a claim of ownership that is so emphatic it almost sounds desperate, encourage another reading -one that does not interrogate the foundations but the outcome of a northern narrative premised on relations of exploitation?

\section{DWARFED}

Whether they are part of the fairy-tale or its dystopian transformation, the characters have their stature belittled. In the first instance, the "dwarves" the woman greets from the Emmy Awards (Jarman 44) do not so much resemble the diminished men who intervene as mediators in Snow White's socialization (Bacchilega, "Cracking" 5), than Disney's heigh-hoing miners digging from early morn till night, before the evening sees them repair to a spotless home. Although the nature of the men's labour is never disclosed, their industriousness retains them at the line station long after work instructions have stopped reaching them: "An electronic detection system warns us if bears are sneaking close while we're working outside the Quonsets with our big hoods up, wind singing loud as jets" (Jarman 31). But when they do leave the line station to head for the coast, the narrator and his protégée turn their backs on the fairy-tale setting and re-enter the northern narrative as "dwarfs," their presence barely noticeable in the immensity surrounding them:

It's uphill and downhill, a plodding broken hike, and unreliable ice in the straits. The two of us follow the old stone cairns, dwarfs in the vast landscape, lunar explorers, endless lost horizon and cliffs like calipers, white mountains, wracked spinning shore, wind penetrating like a wish, but the sky clear and no bears taking a lively interest. (Jarman 40, emphasis added)

As with the vigil of the pre-Columbian ravens over the ice-bound ship, the simile "like calipers" is both visually arresting and historically relevant since it conjures up the image of two huge rock faces portioning the immensity of the sky, but also the measuring gaze of those who have preceded the couple on the same terrain. A similar effect is achieved by the unexpected use of the word "scrimshaw" in a subsequent description: "White mountains far away, and dark lines of whalebone scrimshaw" (Jarman 45). Because the word refers to the carving art sailors developed on whaling ships, it aptly describes a landscape of black lines chiselled on a white background, while also recalling the presence of the sea mammals and (once)

7 The spelling difference calls attention to the story's different generic regimes, "dwarves" takes us back to the quaint diction of the Grimm original whereas "dwarfs" is more suited to a realistic context. Disney, however, did not retain the old-fashioned spelling in their 1937 adaptation of the tale. 
abundant fish-stocks that originally drew European fishing boats to the cold waters of the Northwest Atlantic, and the Arctic beyond. In the passage cited above, the Gaelic "cairn" works to the same effect insofar as it is used preferably to the more local inukshuk. Both are directional markers, but the stones the Inuit have for so long been stacking up in the shape of a person to offer guidance and reassurance on the tundra, humanize the Arctic landscape in a way a line of cairns cannot quite match. In this sense, inuksuit, the plural form of inukshuk, are also miniature men whose benevolent presence is remarkably absent from a story in which the figure of the dwarf possesses a far more ambivalent value. If fairy-tale dwarves are associated with the exploitation of a passive nature and the development of a capitalistic economy of extraction, ${ }^{8}$ this power relation is reversed in the northern narrative whenever the Arctic actively dwarfs southern attempts, no matter how unobtrusive, to master its geography, viz. the domestication of the wild which begins as early as in the incipit with the landscaping gaze embracing "this garden of stone and ice abutting water's wind-wrenched green map" (Jarman 26).

As the animal emanation of the Arctic, the polar bear embodies the formulaic duality of the North, the seduction of its embrace, but also its recalcitrance against intrusions from the south and the forms of exploitation they prepare for. The bears' ubiquitous presence (or worse, their absence for, in this case, they must be hiding close) obsesses the characters who see the animals rise ungainly to the window of the men's shelter to observe their human preys (Jarman 45). In fact, the white bears are the only true giants in "My White Planet," and their huge silhouettes, as they tower above him, call to the narrator's mind the ambivalent memory of a love laced with fear, when "the world [was] a snapping laundry line, your mother a giant in blue sky" (Jarman 43). It is remarkable that the vulnerability of infancy, triggered as it is by the prospect of a bear's smothering embrace, should also be part of the anxieties the fairy tale traditionally alleviates, every time a happy ending brings the reassurance that even the weakest or the most humble can prevail in the face of inordinate hardship, provided one is courageous or astute enough.

The reassuring potential of fairy tales has probably received as much scholarly attention as its flip side, the shaping of gender and social attitudes inherent to them (Bacchilega, Introduction 7). In the present case, however, the tale's comforting message loses much of its original efficacy, troubled as it is by the interference of the other genres the story draws upon. Because of its affiliation to the northern narrative and its dystopian avatars, "My White Planet" is rendered more place-specific than the fairy tale formula can tolerate every time a vivid detail adds definition to the story's spatial and temporal coordinates. According to Jolles, it is the

8 The dwarves' occupation became more specific with each rewriting of the Grimms' transcription. In the first printed version, they are mining "for ore and gold," an addition to the 1810 manuscript which mentioned a nondescript mine. The diamonds and rubies glittering in the Disney animated movie constitute a further embellishment, with a didactic nugget embedded in the "Heigh-Ho" lyrics for good measure: "It ain't no trick to get rich quick / If you dig dig dig with a shovel or a pick" (Zipes 65). 
non-descript character of the fairy tale that defines it as a "simple form": its general terms (a forest, a castle, a king, once upon a time, etc.) make it all encompassing. When particularities narrow its relevance -as is the case with specific dates and locations or a conspicuously original style- the tale will gain in actuality, but lose in generality and therefore tend towards the sophisticated form of the short story (Jolles 113). As a result of this, Jarman's Arctic has none of the timeless, everlasting quality found in a ballad by Robert Service or a Lawren Harris landscape. Instead a number of strategic synecdoches (as shown by the use of "Aztec," "caliper" and "scrimshaw") intersperse the narrative and point to the Arctic's first period of settlement, the exploration age and its present-day exploitation. These tropes unobtrusively restore a historical depth to the space against which this tale of survival can be measured as in turn formulaic and singular, the object of déjà-vu, but also an attempt to destabilize and inflect the topoi long associated with the pristineness of the Arctic.

There is perhaps no better indication of the morphing of the fairy tale into a dystopian short story than in the screens and mirroring surfaces that proliferate in "My White Planet." Although these windows upon the world initially keep the men in touch with what lies beyond their outpost, the same surfaces gradually come to materialize their vulnerability: "I remember the naked white body rolling in icy seawater, the window into the self-righting oil-rig lifeboat, that window like a TV and we stared in like the bears stare in at us. Outside the window it's death" (Jarman 42). The fairy-tale's perspective on the future is obstructed here, for the window in "My White Planet" does not frame a birth to come but reflects fantasies of consumption and destruction. Put differently, Snow White's lifeboat is already a glass casket. Meanwhile, down South, the Evil Queen's magic mirror has become mute, leaving the team to their own devices: "Nothing over satellite anymore, food stopped in our mouth as the satellite feed stopped: no death star, no blues channel, no idea what's out there still", we read. "May 1 brought brief pictures of Ho Chi Minh, stigmata, a Warhol banana, an AK-47. What is happening out there past the clouds of mosquitoes?" (Jarman 31).

Jarman writes of a connected Arctic awash with information. The polyptoton food/feed is a clear indication of the role played by the image diet that sustains McLuhan's global village all the way to the North Pole. But when the team stops receiving messages after the mysterious incident reported on 6/11, it is as if "the authority in the mirror" (Bacchilega, "Cracking" 3) had lost its power. The stream of messages thins to a trickle then stops. Computer screens go blank, the flow of emails also dries out, and the VCR breaks down: "Our cranky VCR works for a while, we're happy again, then nothing again. Snow so industrious on the screen" (Jarman 34, original emphasis). The last sentence foregrounds the porosity between landscape and infoscape, when the latter has surreptitiously come to replace the former in a multi-connected electronic universe.

But once their connection with the South stops and their actions are no longer monitored, the men's labour routines become less constraining and vast stretches of time open they have trouble filling. The team compulsively watch the few TV channels that still operate or the VCR when the latter can be coaxed into 
playing old recordings. It is illustrated books, however, that provide the ultimate reservoir of visual stimulation and simulation the narrator craves:

Now in the afternoons I read to her, our orphan, from old British picture books and periodicals.

$[\ldots]$

These are farmkids chasing a greased pig.

This is a bi-plane.

This is a black bathing suit, a red guitar.

This diamond ring [sic]. (Jarman 29, original emphasis, see also 32, 34, 38)

In the various lists that dot the story, a litany of deictic pronouns bring into existence a cluttered consumer world where consumer goods and energy stand in high demand. Every time the narrator points to a picture, his gesture triggers a dialectical opposition between here and there, close and far, warm and cold, through which the South gains consistency as a noisy, temperate but most of all separate world against the silence and absence that implicitly define the North from a southern perspective: "First a video channel, then a shopping channel. Ads for heroic pickup trucks bashing and splashing through rivers, the mad colours of a lost world. When did I last drive anything with wheels and a heater? Did the world go away or did we? Its whisper-quiet ride, its no money down o.a.c" (Jarman 38-39). What happens, however, when the two worlds collide or, rather, when one intrudes into the other, challenging the distance that guarantees their distinct, yet mutually dependent existence?

\section{BREAKING ICE}

The arrival of the cruise ship on the Arctic shore is staged in slow motion with a display of the verbal pyrotechnics Glover has analysed as characteristic of Jarman's style (114). The short story reaches its climax at the exact moment when the spell is broken and Snow White is released from the land of (dis)enchantment to resume her existence as an entertainment princess in Hollywood:

Then she says she sees its smokestack in the bright icebergs. [...]

Bright daytime but I fire the flare and half a day later the confident hull smashing black and white Dalmatian ice just for her, smokestack's lipstick red stripe just for her, ice shot through with zigzags, shadow lines, the ice a white kitchen floor suddenly buckling up, a bright breaking world roaring below sous chefs grinning at the ship's rail and white shag stateroom where Brooklyn tourists bray Hope we see a bear!! Buffets, fresh Italian bread, pepper steak, blueberries, green eyes and the exact shadow of this ship laid on the ice. (Jarman 40-41, added emphasis in bold, italics in original)

The ship's arrival causes collisions at several levels: phonic ones with the many alliterations in /b/ that bridge the gap between the tourist crowd and the local predators, the domestic space of the kitchen and the wilderness, hot and cold coming here together into a turmoil of sensations upsetting the structural opposi- 
tion between the raw and the cooked with which human societies came into existence, according to Levi-Strauss (1969).

The collision is also a visual and olfactory one between Arctic ice and the splash of colours and fragrant smells that sail into the picture along with the ship, the impact causing, once again, an unexpected contamination. As the ice cracks and dark seawater seeps through, whiteness gets redistributed across the latitudes, and clearly becomes a southern privilege synonymous with the affluence and power concentrated in the temperate zones of the globe. The ship's "white shag stateroom," for instance, is resonant with the erotic fantasies the bear's white fur prompts in the narrator's mind, "squinty black eyes hiding in that expanse of white rug (and I think of her naked on a fireside rug, bearskin, jealous of Malibu, the old highway)," which announces the ultimate displacement of the bear's feral aura onto Snow White when she reappears on a screen with Prince Charming by her side: "On TV we see her on Infotainment Tonight. She is shacked up with one of Jack Nicholson's sons. [...] The cameras love our dream girl and Junior winks, their teeth white as bears on ice" (Jarman 45 and 42, original emphasis). Both the television and the icebreaking ship facilitate the circulation of people, information and values across long distances and along smooth channels of communication, proffering objects of desire to the view of audiences across the world, encouraging consumption on a global scale.

It seems no coincidence then that the close-up on the princely couple's glistening teeth should find its counterpart in the red stripe which turns the ship's smokestack into a sexy, open mouth. The detail is important enough to deserve an earlier mention preparing for the arrival of the ship, when the narrator first casually remembers that "[a] big boat with a stripe the red of lipstick used to call once a year" (Jarman 39). The colour cannot fail to evoke Snow White's crimson lips, the promise of a budding sexuality, but also the Evil Queen's smirk and the bright apple with which she tempts her rival. If the smokestack resembles a mouth, a question arises as to what it may in turn exhale or devour, lipstick throwing a seductive gloss over the appetites of the ship and her passengers. A parallel may here be drawn with the opening of Rudy Wiebe's "The Angel of the Tar Sands" (1982) in which "candy-striped chimneys" blow out dark smoke that vanishes instantly in the crisp blue sky of Fort McMurray (188). Nods to "Hansel and Gretel" (1812), another Grimm fairy tale, frame Wiebe's story, cautioning those who would be tempted to see in the Canadian North an immense gingerbread house oozing out oil, "sweet and clear like golden brown honey" (191). As in the above, the red stripe gracing the curvaceous smokestack encircles the invisible presence of a resource which is going up in smoke, yet remains necessary to operate the ship and keep her passengers comfortable in the various guises of food, clothing, heating, lighting, information and entertainment.

Without the power of oil, none of the tourists on the cruise ship could have ventured so far up North to enjoy spectacular views of its icebergs and charismatic fauna, preserved for as long as the cold will last. The arrival of the ship occasions a lavish display of colours, sounds and smells that appeal to the senses while obliterating what makes this extravagance possible. In this sense, the landing perfectly illustrates the productive paradox formulated by Sheena Wilson, Adam Carlson 
and Imre Szeman in their introduction to Petrocultures: "The importance of fossil fuels in defining modernity has stood in inverse relationship to their presence in our cultural and social imaginaries, a fact that comes as a surprise to almost everyone who engages in critical explorations of energy today. ... Fossil fuels have managed to be hidden in plain sight" (5). For scholars concerned with the far-ranging transformations made necessary by the exhaustion of fossil fuels and the energy transition, the challenge resides in "making visible this socially invisible substance" (6). In this respect, stories certainly have a role to play in creating an awareness of oil problematizing what has so far remained a puzzling absence in the fiction written in countries that are the world's largest energy consumers, a point made by Amitav Ghosh (2002) as early as 1992.

Is our culturally inured indifference to oil the reason why some of the short story elements may easily pass unnoticed, although they play a decisive role in its outcome? The offshore oil-rig disaster that initiates the plot, the prime reason why the woman ended up in an emergency lifeboat, is kept outside the scope of the narrative. Scattered remarks, however, instil the story with a pervading sense of exhaustion, as with the team's dwindling stock of fuel, or the persistent sound of airplanes flying overhead, "until the fuel drains, flying on fumes, vapours wavering like ghosts inside steel rivets" (Jarman 28 and 33 respectively). But scarcity definitely sets in after Snow White has departed along with the promise of abundance she stands for -the cornucopia of warmth and wealth fuelled by invisible oil, extracted up North but consumed down South:'

In the cold hangars and Quonsets we're down to the last barrels of naphtha, diesel (someone is sniffing it), the last juice crystals while on the cruise ship they eat strawberries from Mexico. I could always fry up some liver I suppose, end it all with poisonous liver, but I like it here, these contorted icefields have become my vast home [...], Adam and Eve now gone from the postwar suburb. (Jarman 43)

When he decides to head for the line station, the narrator turns his back on the hyper-consumption encouraged by the agents of globalization -the ubiquitous strawberries made available by NAFTA clearly feature among them. The hint to the postlapsarian era that began after WWII, points to the limits of an Edenic fantasy premised on a boundless access to the earth's resources and disseminated worldwide with the development of global networks of communication. With this move, the man follows in the footsteps of the countless romantic heroes who have sought refuge in the Arctic away from the corruptions of their own time, often losing their life in the process, a possible scenario suggested here by the closeness between "vast home" and "last home." The story, however, opts for a different course, one

${ }_{9}$ Oil is conveyed south through invisible pipelines, which poses further difficulties: "The representative dilemma of confronting everyday oil's representative banality is tied to its sheer opacity [...] and confirms the added challenge of depicting multiple extremely productive but relatively unspectacular objects and routes of transmission. As a rule, pipelines are dull” (Macdonald 42). 
that contemplates the possibilities for survival in the Arctic after the fairy tale has ended, and Snow White has been shipped back to the land of ravenous consumerism: "I jump on my tiny trampoline, do pushups, fat boiling on burners, eating shorebirds when I can catch them. We are alone up here, we're watching out for those two polar bears. They want us, they love us so much, and they do anything they want" (Jarman 44). The narrator's routine combines the rituals of a muscular masculinity with an ascetism inspired of traditional Inuit living, one which, ironically enough, the global reach of petromodernity has all but eradicated. ${ }^{10}$

It is hard to fight off the malaise that arises whenever indigenous resourcefulness is called upon to rescue the white men who seek refuge in the wilderness to survive the "advancing decadence, greed and rapacious cruelty of white civilization" (Atwood 44), and thereby earn a certain measure of indigenization for themselves. This element is undoubtedly present in "My White Planet", but it is undercut by further irony when indigenization faces the prospect of a polar bear's embrace. The ultimate replacement of flirtatious Snow White by two hungry polar bears ${ }^{11}$ calls attention to the distinction the team strived to maintain between desire and need -the law of culture and the call of nature- when confronted to their own carnal appetites: "The old rules don't apply here. [...] We've been good. We've been stupid. Why can't we just do what we want?" and, further on, "Would it have been so bad to breathe of her? Would the world have ended?" (Jarman 35, 43). To these radically ethical questions, the short story proposes a revealing answer in the scene where the narrator waves his paramour away, and forsakes all hopes of claiming the white planet all for himself: "No one will ever know me the way she could have -I'm a prince and a janitor both. We killed Rassy because of her" (Jarman 41). The revelation of the collective murder perpetrated by the team reinstates the limits a human community will oppose to its members' boundless desires to create a space where the individual stands protected from the competing desires of others. The narrator and central character of "My White Planet" emerges in extremis as ethically responsible when he renounces his princely claim to his "charcoal-eyed dream girl" (Jarman 27), her kingdom and its riches, to embrace the position of janitor, caretaker and keeper of the passageway.

The English "janitor" stems from the Latin word for door, ianua, from ianus, arched passageway, which is also the name of Janus, the guardian god of portals, doors and gates, the patron of beginnings and endings often represented as having two faces, alternatively showing a sunrise or a sunset (OED n.p.). In ancient Rome, Janus's temple was open in times of war only, when the empire was facing uncer-

\footnotetext{
10 "Petromodernity refers to a modern life based in the cheap energy systems long made possible by petroleum" (LeMenager 60 ).

${ }_{11}$ I am aware, even as I am writing this, that polar bears are indeed starving to death in the Canadian North, a consequence of global warming that could hardly have been anticipated a decade ago, although efforts to document the disintegration of Arctic and Antarctic ice shelves date back to the mid 1990s. See National Snow and Ice Data Center. State of the Cryosphere. https://nsidc. org/cryosphere/sotc/iceshelves.html.
} 
tain prospects. Jarman is also writing of a dangerous liminal moment when the white man's planet has seemingly shrunk down to the proportions of a tiny trampoline, gravity pulling the man back to its small spherical surface every time he tries to rise higher. "Exactly how little you need -I'm still waiting to find that out," the man finally admits (Jarman 43). The short story postpones the answer indefinitely. But the didactic rhetoric of the fairy tale, as it casts an ironic light on the remains of Canada's northern narrative, balances its more dystopian accents with a sense that the world can indeed be re-enchanted, should one take a stand against the destructive consequences of ravenous models of consumption upon its most fragile environments.

The interlocking of land and ice that went on blocking access to the Pacific even after Knud Rasmussen first crossed the Northwest Passage has by now ceased to be the obstruction against which the West so long exerted the conjoined powers of science and the imagination. Although the position of Canada's Arctic lands arguably remains the same on a world atlas, their positioning has shifted in geostrategic, environmental as well as symbolical terms. The opening of the Northwest Passage and the attention this event focussed on the effects of "global heating," as geographer Kathryn Yusoff provokingly puts it in the epigraph, have made it impossible for Canada to continue imagining its most northern reaches as inaccessible, their remoteness and extreme climate insulating them from southern excesses. Cultivating views of the Arctic as a sanctuary, a reservoir of clean air and dazzling ice swathed in eternal silence, its self-regenerating pristineness immune to all forms of degradation, has become both untenable and problematic in the sense that they obfuscate environmental challenges of planetary scope. These transformations encourage us to reconsider the strategic place of Canada in the context of globalization where expressions of national positioning, far from being obsolete, call for an urgent redefinition so active care for the environment may replace century-old patterns of triumphant exploitation.

Reviews sent to author: 21 October 2018

Revised paper accepted for publication: 26 November 2018 


\section{WORKS CITED}

Atwood, Margaret. Strange Things. The Malevolent North in Canadian Literature. Oxford: OUP, 1995. Print.

Bacchilega, Cristina. "Cracking the Mirror: Three Revisions of 'Snow White'." boundary 2 15-16.1 (Spring-Autumn 1988): 1-25. Print.

Bacchilega, Cristina. Introduction. The Fairy-Tale Web: Intertextual and Multimedial Practices in Globalized Culture, A Geopolitics of Inequality. Detroit, MI: Wayne State UP, 2013. 1-30. Print.

Baldwin, Andrew, Laura Cameron, \& Audrey Kobayashi, eds. Rethinking the Great White North: Race, Nature, and the Historical Geographies of Whiteness in Canada. Vancouver, BC: U of British Columbia P, 2011. Print.

Barthelme, Donald. Snow White. New York: Bantham, 1965. Print.

Buzzati, Dino. The Tartar Steppe. 1938. Trans. Stuart C. Hood. New York: Farrar, Strauss \& Young, 1952. Print.

Carey, Peter. "A Windmill in the West." The Fat Man in History. London: Faber, 1980. 137-147. Print.

Coetzee, J.M. Waiting for the Barbarians. 1980. New York: Penguin, 2010. Print.

Coleman, Daniel. White Civility: The Literary Project of English Canada. Toronto; Buffalo: U of Toronto P, 2006. Print.

Frye, Northrop. "Conclusion to A Literary History of Canada." The Bush Garden: Essays on the Canadian Imagination. 1971. Toronto: Anansi, 1995. 215-263. Print.

Ghosh, Amitav. "Petrofiction: The Oil Encounter and the Novel." The Imam and the Indian. Prose Pieces. Delhi: Ravi Dayal Publisher, 2002. 75-89. Print.

Glover, Douglas. "How to Read a Mark Anthony Jarman Story." Attack of the Copula Spiders and Other Essays on Writing. Windsor, ON: Biblioasis. 2012. 105-114. Print.

Grace, Sherrill. “Gendering Northern Narrative.” Echoing Silence: Essays on Arctic Narrative. Ed. John Moss. Ottawa: U of Ottawa P, 1997. 163-182. Print.

Grace, Sherrill. Canada and the Idea of North. Montreal: McGill-Queen's UP, 2001. Print.

Hulan, Renée. Northern Experience and the Myths of Canadian Culture. Montreal; Ithaca: McGillQueen's UP, 2002. Print.

“Janitor." The Oxford English Dictionary. 1989. 12 March 2018. Web <http://www.oed.com.www. ezp.biu-montpellier.fr>.

Jarman, Mark Antony. "My White Planet." My White Planet. Stories. Toronto: Thomas Allen Publishers, 2008. 25-45. Print

JAY, Paul. Global Matters: The Transnational Turn in Literary Studies. Ithaca, New York: Cornell UP, 2010. Print

Jolles, André. Formes simples. Trans. Antoine Marie Buguet. Paris: Seuil, 1972. Print.

LeMenager, Stéphanie. "The Aesthetics of Petroleum, after Oil!" American Literary History 24.1 (Spring 2012): 59-86. Print.

Levi-Strauss, Claude. The Raw and the Cooked. Trans. John \& Doreen Wheightman. New York: Harper \& Row, 1969. Print. 
Lorre-Johnston, Christine. “A little more erratic': An Interview with Mark Anthony Jarman." Short Fiction in Theory and Practice 7.2 (2017): 205-212. Print.

Macdonald, Graeme. "Containing Oil: The Pipeline in Petroculture." Petrocultures: Oil, Politics, Culture. Ed. Sheena Wilson, Adam Carlson, \& Imre Szeman. Montreal; Kingston: McGillQueen's UP, 2017. 36-77. Print.

McCaffery, Larry. “Barthelme's Snow White: The Aesthetics of Trash.” Critique 16.3 (1976): 19-32. Print.

“Milestones in Space Photography.” National Geographic (31 Jan 2018). 6 April 2018. Web < https:// www.nationalgeographic.com/photography/photos/milestones-space-photography/>.

Moss, John. Enduring Dreams: An Exploration of Arctic Landscape. Toronto: Anansi, 1996. Print.

National Snow and Ice Data Center. State of the Cryosphere. Last updated 12 Feb 2018. 12 March 2018. Web <https://nsidc.org/ cryosphere/sotc/iceshelves.html>.

Nealon, Jeffrey T. "Disastrous Aesthetics: Irony, Ethics and Gender in Barthelme's Snow White." Twentieth Century Literature 51.2 (Summer 2005): 123-141. Print.

Nischiк, Reingard. The English Short Story in Canada: From the Dawn of Modernism to the 2013 Novel Prize. Jefferson, NC: McFarland \& Co., 2017. Print.

Ricou, Laurie. "Disturbance-Loving Species: Habitat Studies, Ecocritical Pedagogy, and Canadian Literature." Critical Collaborations. Indigeneity, Diaspora, and Ecology in Canadian Literary Studies. Ed. Smaro Kamboureli \& Christl Verduyn. Waterloo, ON: Wilfrid Laurier UP, 2014. 161-174. Print.

Steger, Manfred. Globalization: A Very Short Introduction. Oxford: Oxford UP, 2013. Print.

Van Herk, Aritha. "Creating Willem Barentsz; Piloting North." Echoing Silence: Essays on Arctic Narrative. Ed. John Moss. Ottawa: U of Ottawa P, 1997. 79-92. Print.

Wiebe, Rudy. "The Angel of the Tar Sands." The Angel of the Tar Sands and Other Stories. McClelland \& Stewart: Toronto, 1982. 188-191. Print.

Wilson, Sheena, Adam Carlson, \& Imre Szeman. "On Petrocultures: Or, Why We Need to Understand Oil to Understand Everything Else.” Petrocultures: Oil, Politics, Culture. Ed. Sheena Wilson, Adam Carlson, \& Imre Szeman. Montreal; Kingston: McGill-Queen's UP, 2017. 3-20. Print.

Yusoff, Kathryn, "Navigating the Northwest Passage." Envisioning Landscapes; Making Worlds: Geography and the Humanities. Ed. Stephen Daniels, et al. London; New York: Routledge, 2011. 299-310. Print.

Zipes, Jack. Fairy Tales and the Art of Subversion: The Classical Genre for Children and the Process of Civilization. 1983. London; New York: Routledge, 2006. Print.

Zipes, Jack. The Irresistible Fairy Tale: The Cultural and Social History of a Genre. Princeton; Oxford: Princeton UP, 2012. Print. 
